Article

\title{
Detection of Groundwater Levels Trends Using Innovative Trend Analysis Method in Temperate Climatic Conditions
}

\author{
Ionuț Minea *(D), Daniel Boicu and Oana-Elena Chelariu $\mathbb{D}$ \\ Faculty of Geography and Geology, Alexandru Ioan Cuza University of Iași, 700506 Iași, Romania; \\ boicu.d.daniel@gmail.com (D.B.); oana.chelariu@uaic.ro (O.-E.C.) \\ * Correspondence: ionutminea1979@yahoo.com; Tel.: +40-741-331-556
}

Received: 24 June 2020; Accepted: 25 July 2020; Published: 27 July 2020

\begin{abstract}
The evolution of groundwater levels is difficult to predict over medium and long term in the context of global climate change. Innovative trend analysis method (ITA) was used to identify these trends, and ITA index was calculated to measure their magnitude. The data used are sourced from 71 hydrogeological wells that were dug between 1983 and 2018 and cover an area of over $8000 \mathrm{~km}^{2}$ developed in the temperate continental climate in the north-eastern part of Romania. The results obtained by applying the ITA show a general positive trend for groundwater level over $50 \%$ of wells for winter and spring seasons and annual values. The negative trends were observed for more than $43 \%$ of wells for the autumn season followed by the summer season (less than $40 \%$ ). The magnitude of trends across the region shows a significant increase for spring season (0.742) followed by winter season (0.353). Important changes in the trends slopes and magnitudes have been identified for groundwater level depth between 0 and $4 \mathrm{~m}$ (for winter and spring seasons) and between 4 and $6 \mathrm{~m}$ (for summer and autumn seasons). The results can be implemented in groundwater resources management projects at local and regional level.
\end{abstract}

Keywords: groundwater level; graphical method; innovative trend analysis (ITA); magnitude; north-eastern Romania

\section{Introduction}

Changes in hydro-climatic and hydrogeological conditions can cause significant disturbances in the natural elements that lead to difficult to predict trends. In this respect, it is a question of identifying methods that are relevant in the medium and long term, because of the lack of adequate monitoring of the hydro-climatic and hydrogeological parameters (air temperature, atmospheric precipitation, river flows, and groundwater level) in some parts of the world [1]. Moreover, the identification of trends in the variation regime of natural elements becomes relevant as the effect of climate change is felt increasingly globally [2]. In the past decades, the scientific research on the impact of climate change on the various hydro-climatic parameters has been multiplied, most of the analyses focusing on the identification of trends in the extreme seasonal and annual values [3,4]. The most commonly used statistical methods for identifying trends was the Mann Kendall test, Sen's slope, and linear regression [5-9]. These methods have also been applied to assess the impact of climate change on groundwater resources [10-12].

Recent scientific research proposes new statistical and graphical approaches to identify trends such as innovative trend analysis (ITA) [13]. This method was used in the analysis of the extreme values of rivers flow [14] or atmospheric precipitation [15,16]. The application of this statistical method is facilitated by the fact that comparative analysis of data series can be done without statistical assumptions such as common parametric and nonparametric trend tests [17-19]. For north-eastern 
part of Romania previous researches based on Mann Kendall test and Sen's slope and linear regression have estimated significant changes in climatic [20,21], hydrological [22,23], and hydrogeological parameters [24] as a result of regional climate changes.

In this context, the main objective of this paper is the application of this novel method to identify the trends and magnitude of the trends of groundwater level under temperate continental climate conditions. This objective is important in the context of increasing impacts of climate change on water resources and can also be considered a starting point in the analysis of underground water resources evolution in close connection with the efficient management of these resources.

\section{Data and Methods}

\subsection{Study Area}

For the detection of groundwater level trends, data series from 71 hydrogeological wells included in 37 hydrogeological stations were used, covering an area of over $8000 \mathrm{~km}^{2}$ in the north-eastern part of Romania (Figure 1). The drillings have been carried out since the 1980s, along Prut river hydrographic network and they are included in the Prut and its tributaries Groundwater body (GRPR02). This is an unconfined groundwater body developed on Sarmatian clay and sandy deposits [25].

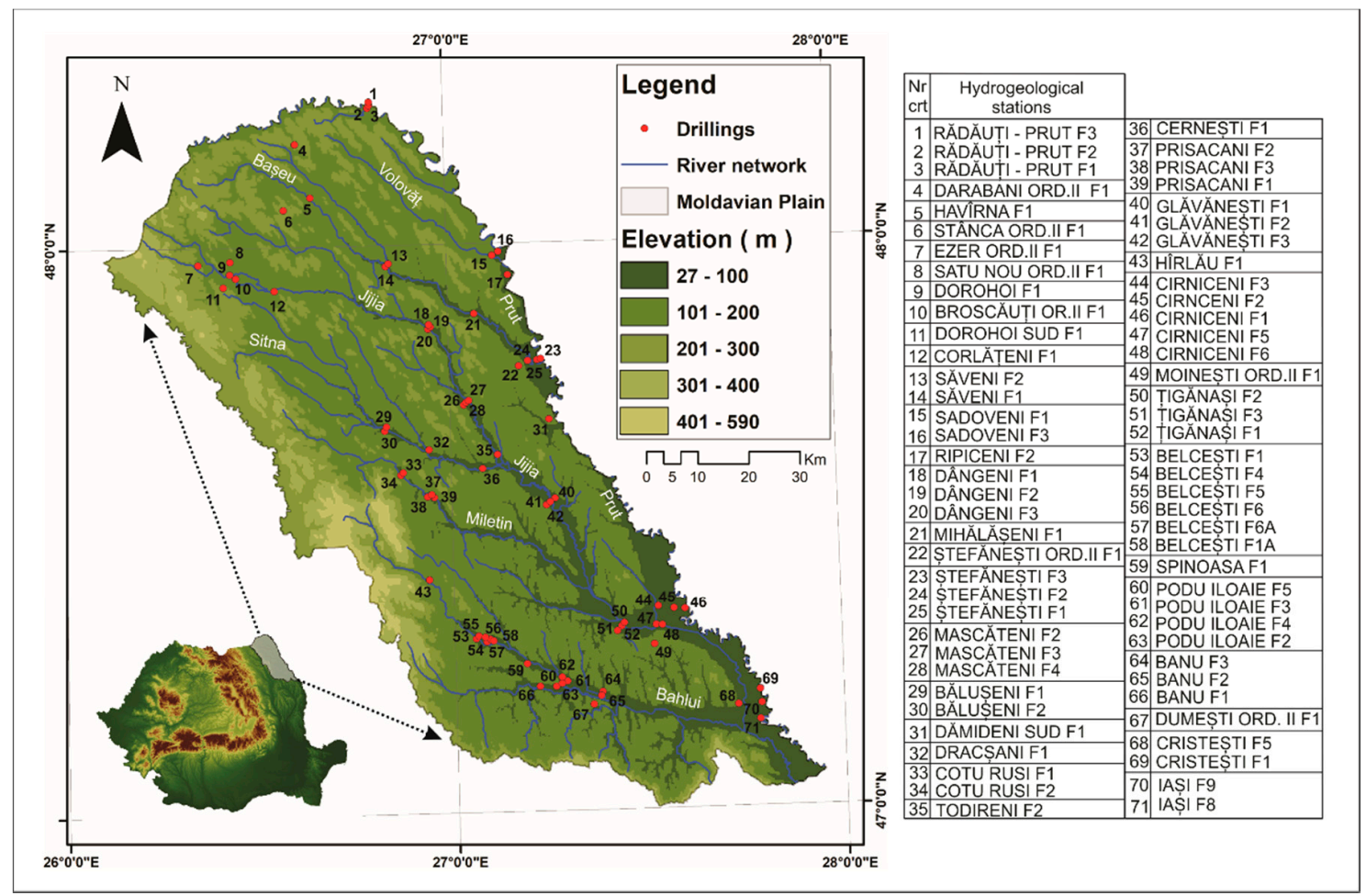

Figure 1. The distribution of wells in north-eastern part of Romania.

In terms of climatic conditions, this region is included in the temperate continental climate with maximum temperatures and rainfall in summer and minimum in winter. The whole region has a relatively homogeneous aspect in terms of natural conditions, with an average annual temperature varying between $8{ }^{\circ} \mathrm{C}$ (in the north part) and $9.5^{\circ} \mathrm{C}$ (in the south part) and average annual rainfall between $550 \mathrm{~mm}$ (in the south) and $650 \mathrm{~mm}$ (in the north). In winter, because of negative average temperatures (from $-6{ }^{\circ} \mathrm{C}$ to $-4{ }^{\circ} \mathrm{C}$ ) [26], precipitation is retained in the form of a snow layer. In this region, significant changes in climatic parameters [27] and hydrological [28] and hydrogeological ones [29] have been identified. Statistical analyses based on seasonal and annual average temperature 
and rainfall data revealed that there is a positive trend for temperature and precipitation specific for spring and autumn, while decreasing precipitation characterizes the winter season [22].

\subsection{Data}

The statistical analysis was based on five time series data sets (four seasonal and one annual) for groundwater level from all 71 hydrogeological wells. The detection of trends was made only based on the series with data sets having no temporal interruptions over the period 1983-2018. The groundwater level data were provided by Prut-Siret Administration Branch of Romanian Waters Administration.

\subsection{Innovative Trend Analysis Method (ITA)}

This method has been applied for different extreme values of hydro-climatic parameters, considering that they have significant serial correlations at least on short memory basins [30]. In this paper, we apply this method to the data series regarding the groundwater level, considering that the measurements regarding the groundwater variation do not have the same accuracy and frequency as those related to the hydro-climatic parameters at the ground level. At the same time, it must be taken into account the fact that groundwater level variations are not as spectacular from day to day, sometimes even from one month to the next, so that the maximum and minimum values merge into average values measured at regular intervals of time. In the Romanian system, the measurements of the groundwater level are carried out every 3 days, and on average, in a month, ten measurements are made on a hydrogeological well. In particular situations, with constant climatic conditions (with alternating days with and without rainfall and without high temperature variations), the measured values do not differ greatly from one measurement to another. Therefore, the average monthly value fully reflects the natural variation of the groundwater level and may be considered as a basic element in the statistical analysis of trends using ITA.

In the first step, this method involves dividing the entire dataset into two equal and orderly series [31]. In the present study for the analysis of trends in the 1983-2018 time period, two sub-series of data, each of 18 years each, were extracted (1983-2000 and 2001-2018).

In stage two, the two sub-series are represented in a two-dimensional Cartesian coordinate system as scatter points and compared to the $1: 1\left(45^{\circ}\right)$ line. After the graphical representation, if some of the points are above the median line, they show an increasing trend, while if they are below the median line, they represent a decreasing trend, and if they are concentrated along the median line they show no trend. Taking into account that in the case of groundwater level the actual measurements relate to the surface of the terrain, the interpretation of the trends is performed inversely to the interpretation of the trends in the hydro-climatic parameters from the surface (Figure 2).
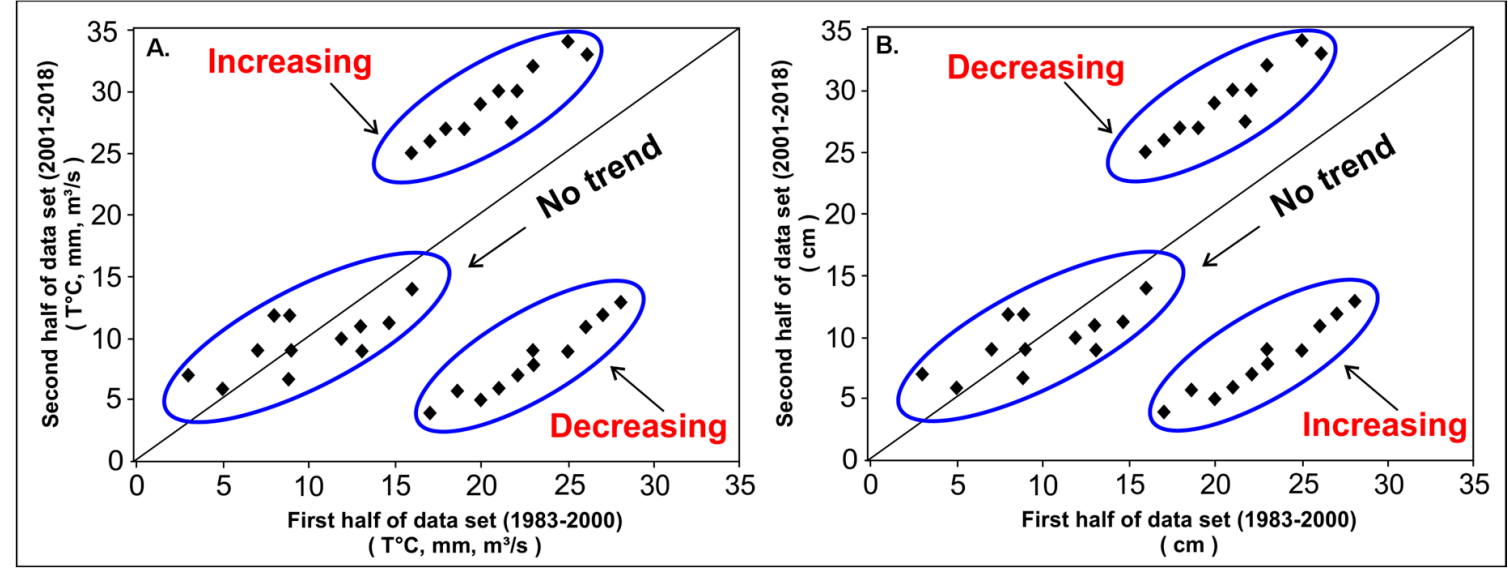

Figure 2. Graphical interpretation for climatic and hydrological parameters (A) and groundwater level (B) trends using innovative trend analysis (ITA). 
Associated with this method, [13] also identifies a formula for estimating the slope:

$$
\mathrm{S}=\frac{2\left(\overline{y_{2}}-\overline{y_{1}}\right)}{n}
$$

where: $\mathrm{S}$ is the slope of trend, $\bar{y}_{1}, \bar{y}_{2}$ are the averages of the first and second series, and $n$ is the total number of the data. In the same time, the confidence limit (CL) of the trend slope must be taken into account. This can be expressed with the formula:

$$
\mathrm{CL}_{(1-\alpha)}=0 \pm \mathrm{s}_{\text {crit }} \sigma_{\mathrm{s}}
$$

where: $\alpha$ is the percent of significance level, $\mathrm{s}_{\text {crit }}$ is standard deviation values [13] and $\sigma_{\mathrm{s}}$ is the slope of standard deviation. For this study the significance for $\alpha$ is $5 \%$. When the slope values are outside the confidence interval, the alternative hypotheses $(\mathrm{Ha})$ is adopted. On this assumption, we can consider that there is a trend in the analyzed data. The type of trend is given by the slope sign, if it is negative the type of trend is increasing (for groundwater level case), if it is positive the type of trend is decreasing and if the slope is equal to 0 there is no trend.

At the same time, the magnitude of the trend can be calculated with ITA index [32] based on the formula:

$$
\mathrm{ITA}_{i}=\frac{1}{n} \sum_{i=1}^{n} \frac{10\left(y_{i}-x_{i}\right)}{\bar{X}}
$$

where $x_{i}$ is the value of the first-ordered sub-series and $y_{i}$ is the value ordered of the second sub-series, $\bar{X}$ is the average of $x_{i}$.

In order to better highlight trends of variation in the level of groundwater for the entire region, the analysis was performed globally and on water depth classes. Five depth classes were achieved: the water depth class ranges between 0 and $2 \mathrm{~m}$ (including 12 wells), the water depth class ranges from 2 to $4 \mathrm{~m}$ (with 26 wells), the class with water depths of 4 to $6 \mathrm{~m}$ (with 14 wells), the water depth class range from 6 to $10 \mathrm{~m}$ (with 12 wells), and class with water depth in wells over $10 \mathrm{~m}$ (with 7 wells). This classification takes into account the mean depth of water and spatial distribution of the wells, most of the drillings being located along hydrographic network, the variation of the water level being influenced by a number of external factors such as the relationship between the groundwater level and the drainage of the rivers under drought conditions or high precipitations [33].

\subsection{Mapping}

For spatial interpolations for both slope and ITA index, the Ordinary Kriging (OK) method was chosen. In the analysis it was considered optimal to use this representation method because the geostatistical analysis revealed that the correlation coefficient between the measured values and the simulated values had the best results at the expense of other interpolation methods [34].

\section{Results and Discussions}

The ITA was applied to all wells and some of the results are shown in Figure 3. Because of the formatting constraints, we have represented in the present paper only 20 graphs resulting from applying this method (for Harlau F1, Banu, F2, Belceşti F1, and Podu Iloaiei F5) out of a total of 355 charts analyzed. The values of the statistical parameters associated with this method can be seen in Supplementary materials.

Taking into account the sign of slopes (positive or negative) across the region, the annual trends are positive for $54.9 \%$ of the wells and negative for $40.8 \%$ of the wells. No trend was recorded in $4.3 \%$ of drillings. Across seasons there are slight changes in the trend ratio. In winter, $52.2 \%$ of the wells registered a positive trend, $38.0 \%$ had a negative trend, and $9.8 \%$ had no statistically significant trend. The percentage of wells with positive trends has the highest value for the whole spring region $(59.2 \%$ 
of wells) because of increased surface water intake through the hydrographic network or infiltration of precipitation (Figure 4).

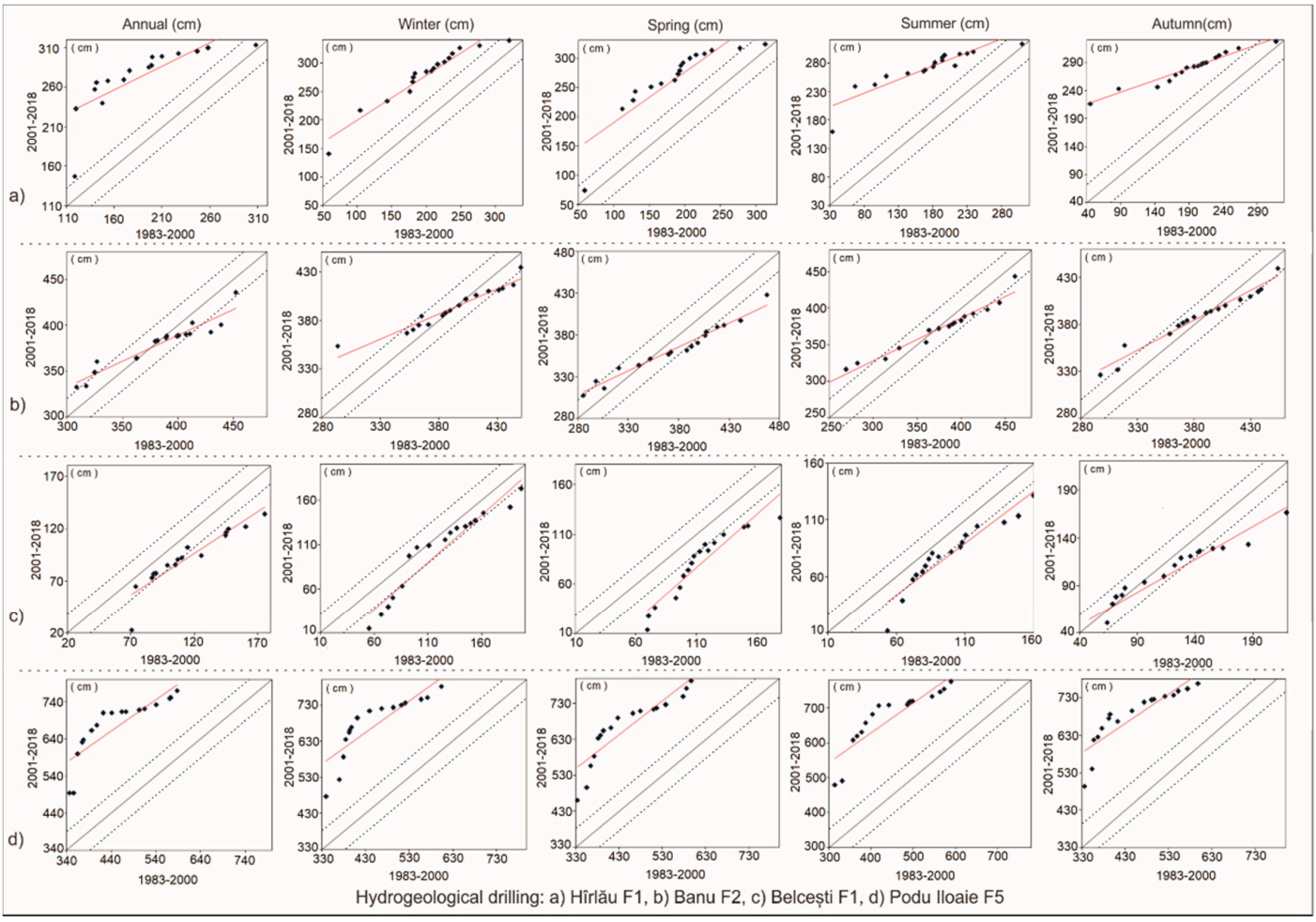

Figure 3. Trend analysis for season groundwater level based on ITA (a) Harlau F1, (b) Banu F2, (c) Belcești F1, (d) Podu Iloaiei F5.

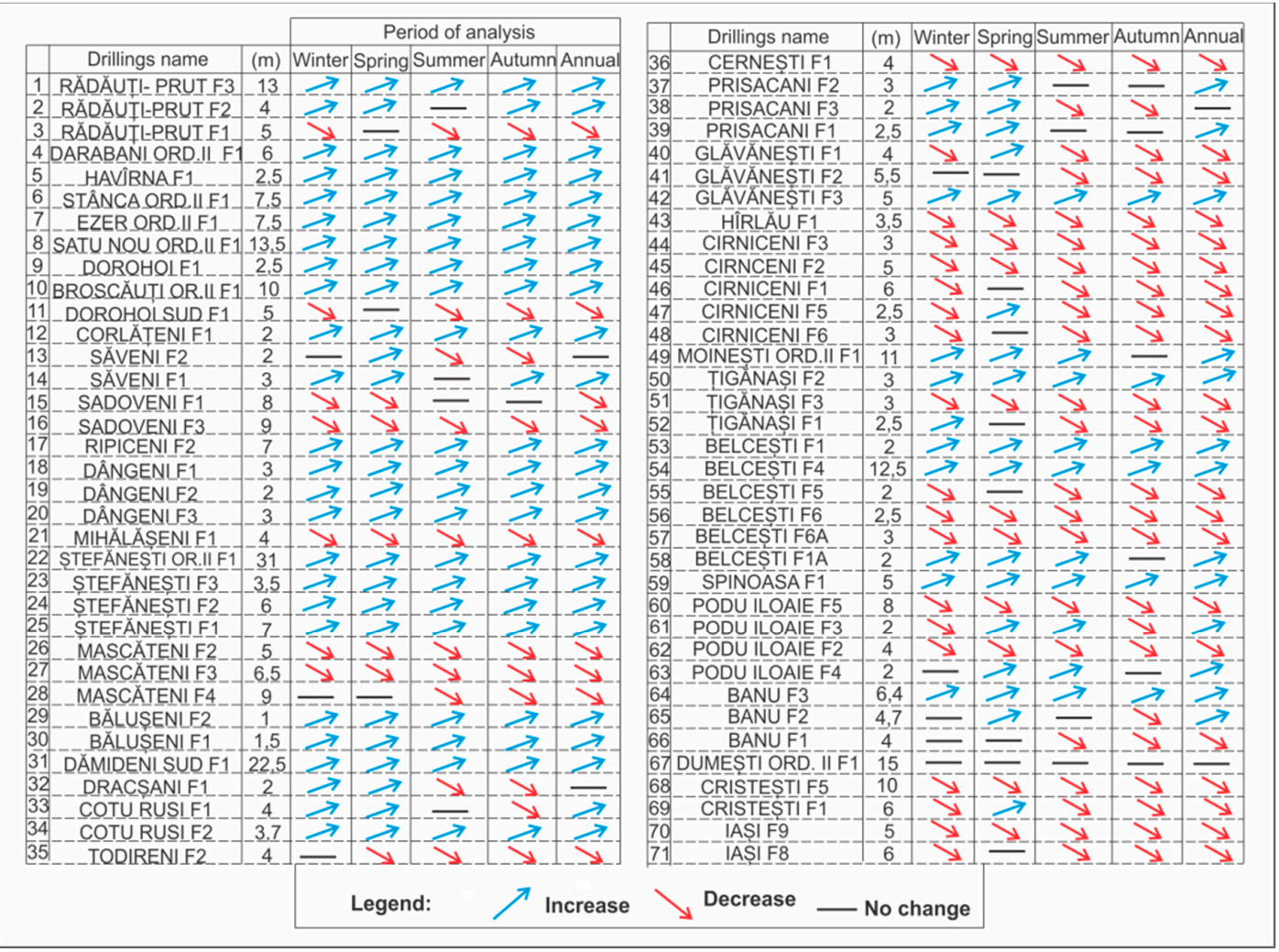

Figure 4. Seasonal and annual trends for groundwater level. 
The lowest number of wells with negative trends (18 wells, representing $25.3 \%$ of the total) are registered in spring. A constant variation of the groundwater level is recorded during this season at 11 wells (15.5\%). The lowest percentage of positive trend wells is registered in autumn (40.8\%), and the highest percentage of wells with negative trends is recorded also in the autumn season (49.3\%). The spatial distribution of slopes shows a general trend of growth in the north and north-west part and declines in the central and south-eastern parts (with small differentiations for the winter and spring seasons) (Figure 5).

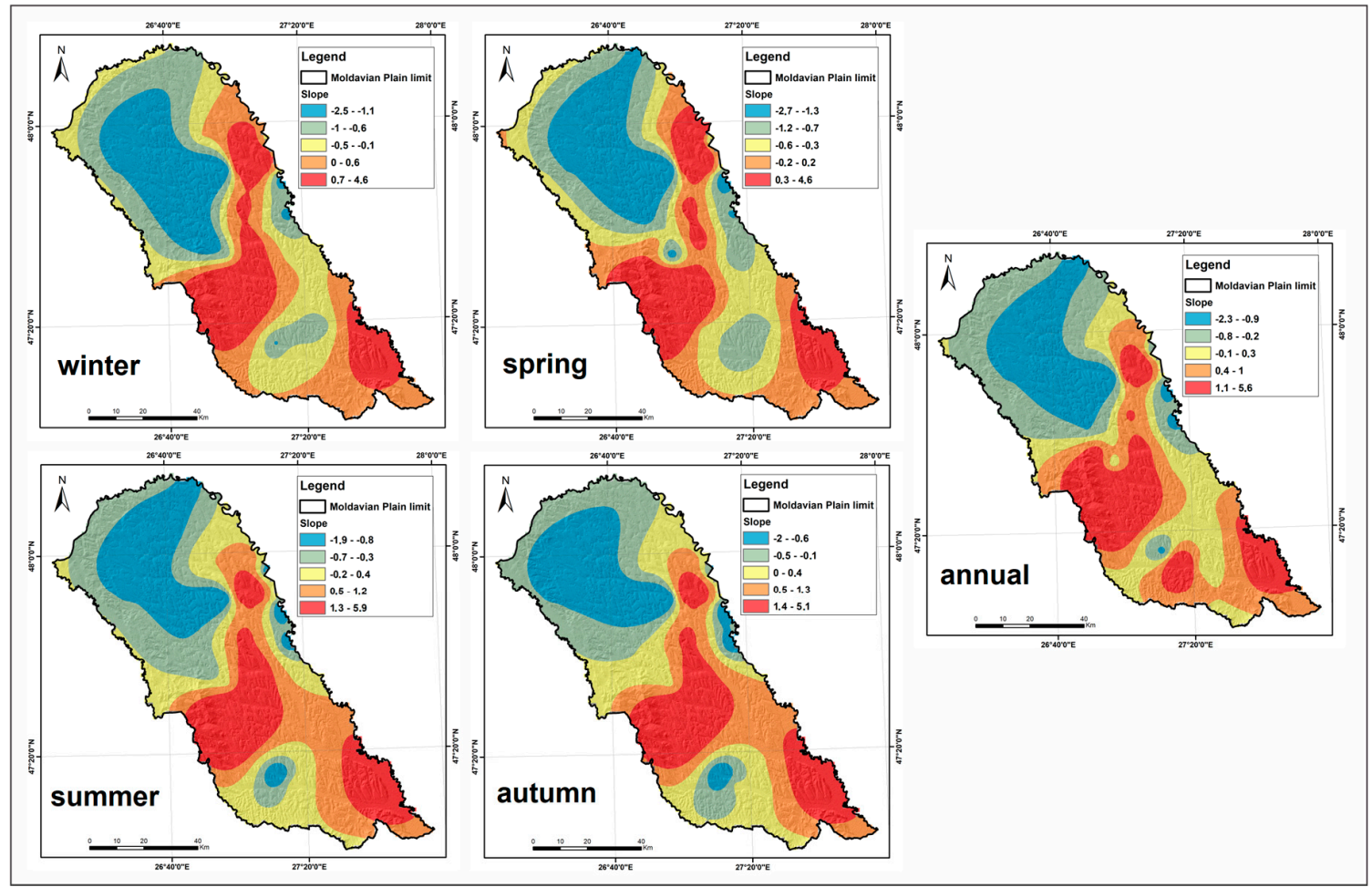

Figure 5. Slope distribution for annual and seasons periods.

On different depth of water levels, it is noted that for the depth class of 0 to $2 \mathrm{~m}, 91.7 \%$ of wells in summer season and $75 \%$ of wells for annual period record positive slopes. The highest percentage of wells with negative slopes is observed in the depth range of 4 to $6 \mathrm{~m}$ (with $71.4 \%$ of the wells) in the autumn season and in the winter and summer season (64.3\% of the wells). Most wells where no trends have been found are in the depth class of 2 to $4 \mathrm{~m}$ (19.2\% from wells in the summer season and $11.5 \%$ from wells in the spring season). Over $85 \%$ of the wells included in the depth class over $10 \mathrm{~m}$ have positive trends both for annual and all seasons (Figure 6). In fact, within this class there was no situation with negative trends of the slope, just for one well no trends were identified (Dumeşti F1) for all seasons.

The ITA index was applied to analyze the intensity of increase or decrease of groundwater level. For the entire region, the ITA index reveals a significant increase for the spring season (0.742) followed by the winter season (0.353). On an annual basis, the increase magnitude of the trends is slightly lower than that of the two season (0.291) because of the influence of the ITA index calculated for summer season (0.121) and autumn season (0.098) (Table 1). The values between +0.1 and -0.1 of the ITA index can be considered without significant statistical increase or decrease of groundwater level. 


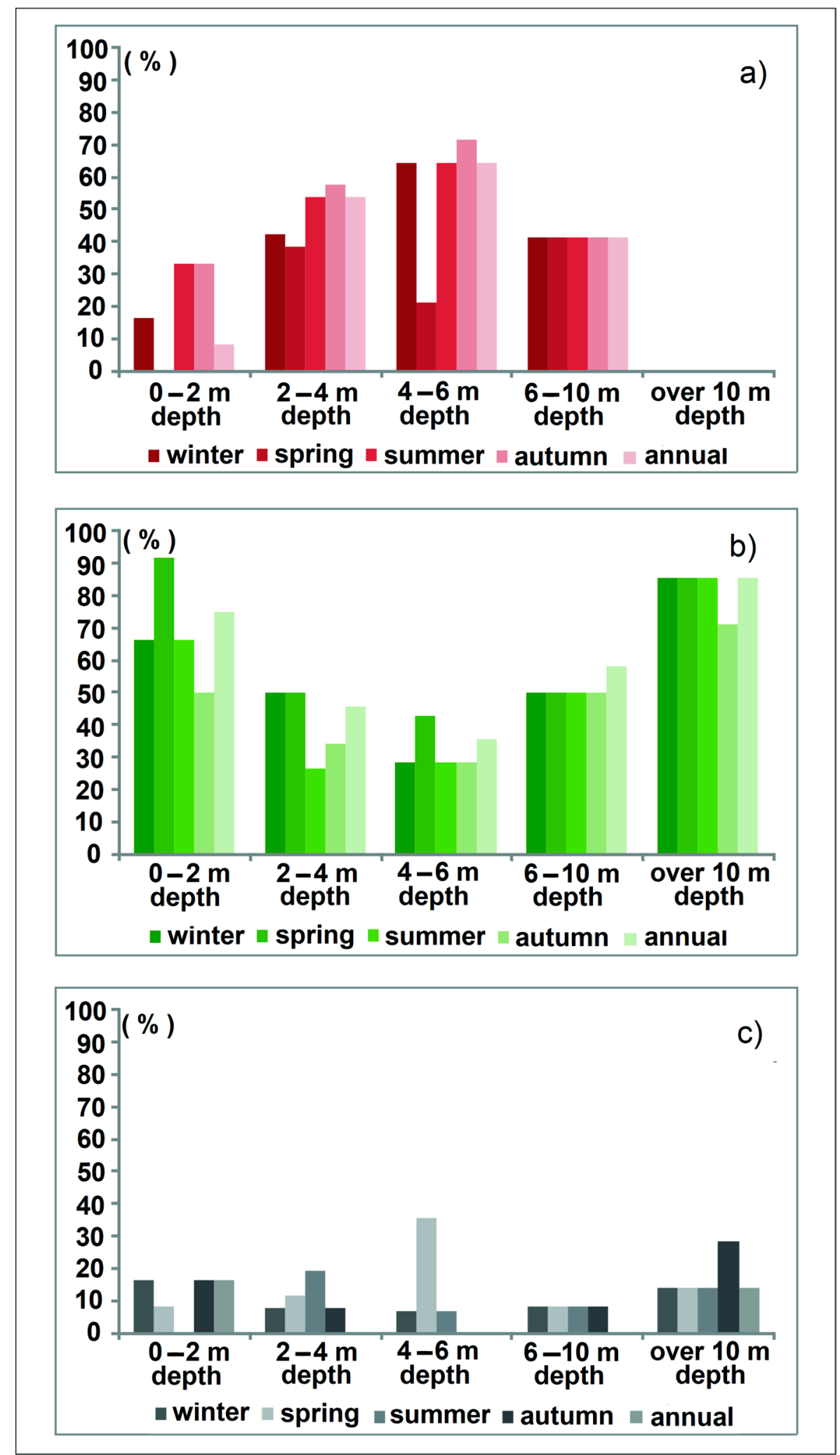

Figure 6. Positive (a), negative (b), and no trend (c) of slope frequency for different classes of groundwater level. 
Table 1. Changes in seasons and annual groundwater level according to the ITA index.

\begin{tabular}{|c|c|c|c|c|c|c|c|}
\hline No. & Well Code & Average Depth (m) & Winter & Spring & Summer & Autumn & Annual \\
\hline 1 & RĂDĂUTI-PRUT F3 & 13 & 0.23 & 0.26 & 0.36 & 0.26 & 0.27 \\
\hline 2 & RĂDĂUȚI-PRUT F2 & 4 & 0.12 & 0.48 & 0.07 & 0.12 & 0.19 \\
\hline 3 & RĂDĂUȚI-PRUT F1 & 5 & -0.19 & 0.004 & -0.16 & -0.11 & -0.11 \\
\hline 4 & DARABANI ORD.I F1 & 6 & 0.94 & 1.33 & 0.24 & 0.44 & 0.74 \\
\hline 5 & HAVÎRNA F1 & 2.5 & 0.7 & 1.11 & 0.59 & 0.47 & 0.7 \\
\hline 6 & STÂNCA ORD.II F1 & 7.5 & 0.61 & 0.79 & 0.7 & 0.5 & 0.65 \\
\hline 7 & EZER ORD.II F1 & 7.5 & 0.34 & 0.46 & 0.14 & 0.24 & 0.29 \\
\hline 8 & SATU NOU ORD.II F1 & 13.5 & 1.67 & 1.74 & 1.52 & 1.48 & 1.6 \\
\hline 9 & DOROHOI F1 & 2.5 & 0.77 & 0.56 & 0.64 & 0.69 & 0.67 \\
\hline 10 & BROSCĂUȚI ORD.II F1 & 10 & 1.53 & 1.64 & 1.82 & 1.63 & 1.65 \\
\hline 11 & DOROHOI SUDD ORD.II F1 & 5 & -0.068 & -0.087 & -0.4 & -0.2 & -0.18 \\
\hline 12 & CORLĂȚENI F1 & 2 & 1.4 & 1.75 & 0.82 & 0.66 & 1.12 \\
\hline 13 & SĂVENI F2 & 2 & -0.018 & 0.33 & 0.42 & -0.26 & -0.12 \\
\hline 14 & SAVENI F1 & 3 & 0.06 & 0.21 & 0.02 & 0.08 & 0.09 \\
\hline 15 & SADOVENI F1 & 8 & -0.02 & -0.04 & -0.02 & -0.01 & -0.02 \\
\hline 16 & SADOVENI F3 & 9 & -0.09 & -0.12 & -0.05 & -0.06 & -0.08 \\
\hline 17 & RIPICENI F2 & 7 & 0.05 & 0.12 & 0.18 & 0.11 & 0.11 \\
\hline 18 & DÂNGENI F1 & 3 & 0.59 & 1.06 & 0.39 & 0.32 & 0.57 \\
\hline 19 & DÂNGENI F2 & 2 & 5.96 & 5.82 & 4.43 & 5 & 5.23 \\
\hline 20 & DÂNGENI F3 & 3 & 1.28 & 1.79 & 1.1 & 0.94 & 1.25 \\
\hline 21 & MIHĂLĂȘENI F1 & 4 & -1.06 & -1.01 & -1.15 & -1.03 & -1.06 \\
\hline 22 & ȘTEFĂNEȘTI ORD.II F1 & 31 & 0.04 & 0.27 & 0.03 & 0.04 & 0.03 \\
\hline 23 & STTEFĂNESTTI F3 & 3.5 & 0.94 & 1.38 & 0.94 & 0.81 & 1.01 \\
\hline 24 & ȘTEFĂNESTTI F2 & 6 & 0.13 & 0.22 & 0.2 & 0.16 & 0.17 \\
\hline 25 & ȘTEFĂNEȘTI F1 & 7 & 0.26 & 0.4 & 0.33 & 0.27 & 0.31 \\
\hline 26 & MASCĂTENI F2 & 5 & -0.33 & -0.33 & -0.43 & -0.36 & -0.36 \\
\hline 27 & MASCĂTENI F3 & 6.5 & -0.18 & -0.15 & -0.36 & -0.33 & -0.26 \\
\hline 28 & MASCĂTENI F4 & 9 & -0.028 & 0.05 & -0.11 & -0.16 & -0.06 \\
\hline 29 & BĂLUȘENI F2 & 1 & 4.25 & 12.1 & 1.77 & 1.13 & 2.93 \\
\hline 30 & BĂLUȘENI F1 & 1.5 & 3.18 & 5.55 & 1.33 & 0.78 & 2.07 \\
\hline 31 & DĂMIDENI SUD F1 & 22.5 & 0.05 & 0.05 & 0.05 & 0.05 & 0.05 \\
\hline 32 & DRACȘANI F1 & 2 & 0.16 & 0.33 & -0.13 & -0.22 & 0.04 \\
\hline 33 & COTU RUSI F1 & 4 & 0.31 & 1.7 & 0 & -0.47 & 0.24 \\
\hline 34 & COTU RUSI F2 & 3.7 & 1.83 & 3.64 & 1.09 & 0.97 & 1.7 \\
\hline 35 & TODIRENI F2 & 4 & 0 & -0.59 & -0.4 & -0.3 & -0.19 \\
\hline 36 & CERNEȘTI F1 & 4 & -0.35 & -0.19 & -0.59 & -0.52 & -0.41 \\
\hline 37 & PRISACANI F2 & 3 & 0.5 & 1.07 & 0 & 0.03 & 0.37 \\
\hline 38 & PRISACANI F3 & 2 & 0.74 & 1.45 & -0.78 & -0.46 & 0.03 \\
\hline 39 & PRISACANI F1 & 2.5 & 0.29 & 1.49 & 0.14 & -0.08 & 0.38 \\
\hline 40 & GLĂVĂNEȘTI F1 & 4 & -0.14 & 0.28 & -0.28 & -0.53 & -0.19 \\
\hline 41 & GLĂVĂNEȘTI F2 & 5.5 & -0.03 & 0 & -0.39 & -0.4 & -0.22 \\
\hline 42 & GLĂVĂNEȘTI F3 & 5 & 0.3 & 0.5 & 0.27 & 0.17 & 0.31 \\
\hline 43 & HÎRLĂU' F1 & 3.5 & -1.3 & -1.4 & -1.8 & -0.5 & -1.5 \\
\hline 44 & CIRNICENI F3 & 3 & -0.61 & -0.74 & -0.75 & -0.75 & -0.71 \\
\hline 45 & CIRNICENI F2 & 5 & -0.45 & -0.51 & -0.49 & -0.56 & -0.5 \\
\hline 46 & CIRNICENI F1 & 6 & -0.1 & -0.02 & -0.2 & -0.27 & -0.15 \\
\hline 47 & CIRNICENI F5 & 2.5 & -0.35 & 0.18 & -0.53 & -0.88 & -0.41 \\
\hline 48 & CIRNICENI F6 & 3 & -0.19 & 0.01 & -0.54 & -0.58 & -0.33 \\
\hline 49 & MOINEȘTI ORD.II F1 & 11 & 0.04 & 0.05 & 0.05 & 0.01 & 0.04 \\
\hline 50 & ȚIGẮNAȘI F2 & 3 & 4.86 & 5.18 & 2.63 & 2.7 & 3.57 \\
\hline 51 & ȚIGĂNAȘI F3 & 3 & -0.96 & -0.9 & -1.34 & -1.25 & -1.12 \\
\hline 52 & ȚIGĂNAȘI F1 & 2.5 & 0.21 & 0.19 & -0.85 & -0.67 & -0.34 \\
\hline 53 & BELCESTTI F1 & 2 & 0.9 & 2.1 & 1.2 & 0.2 & 1.2 \\
\hline 54 & BELCEȘTI F4 & 12.5 & 0.07 & 0.1 & 0.1 & 0.02 & 0.08 \\
\hline 55 & BELCEȘTI F5 & 2 & -0.18 & -0.02 & -0.51 & -0.44 & -0.29 \\
\hline 56 & BELCEȘTI F6 & 2.5 & -0.9 & -0.7 & -1.1 & -0.2 & 0.9 \\
\hline 57 & BELCEȘTI F6A & 3 & -0.6 & -0.4 & -0.8 & -0.3 & -0.7 \\
\hline 58 & BELCEȘTI F1A & 2 & 0.38 & 1.5 & 0.57 & 0.05 & 0.6 \\
\hline 59 & SPINOASA F1 & 5 & 0.21 & 0.13 & 0.3 & 0.12 & 0.23 \\
\hline 60 & PODU ILOAIE F2 & 4 & -0.7 & 0.1 & 0.2 & 0.3 & 0.3 \\
\hline 61 & PODU ILOAIE F3 & 2 & 0.16 & 0.13 & 0.12 & 0.1 & 0.08 \\
\hline 62 & PODU ILOAIE F4 & 2 & 0.1 & 2.1 & 0.9 & 0.04 & 0.63 \\
\hline 63 & PODU ILOAIE F5 & 8 & -1.63 & -1.57 & -1.64 & -0.5 & -1.62 \\
\hline 64 & BANU F3 & 6.4 & 0.16 & 0.16 & 0.06 & 0.04 & 0.13 \\
\hline 65 & BANU F2 & 4.7 & 0.02 & 0.2 & 0.03 & 0.013 & 0.04 \\
\hline
\end{tabular}


Table 1. Cont.

\begin{tabular}{cccccccc}
\hline No. & Well Code & Average Depth $(\mathbf{m})$ & Winter & Spring & Summer & Autumn & Annual \\
\hline 66 & BANU F1 & 4 & 0.03 & 0.06 & 0.27 & 0.05 & 0.1 \\
67 & DUMESTI ORD.II F1 & 15 & 0.01 & 0 & 0 & 0 & 0 \\
68 & CRISTEȘTI F5 & 10 & -0.41 & -0.39 & -0.43 & -0.45 & -0.42 \\
69 & CRISTESTI F1 & 6 & -0.17 & -0.11 & -0.29 & -0.33 & -0.17 \\
70 & IASSI F9 & 5 & -0.17 & -0.18 & -0.51 & -0.46 & -0.33 \\
71 & IAȘI F8 & 6 & -0.08 & 0.05 & -0.38 & -0.35 & -0.19 \\
\hline \multicolumn{2}{r}{ Average } & & $\mathbf{0 . 3 5}$ & $\mathbf{0 . 7 4}$ & $\mathbf{0 . 1 2}$ & $\mathbf{0 . 1 0}$ & $\mathbf{0 . 2 9}$ \\
\hline
\end{tabular}

For the depth class between 0 and $2 \mathrm{~m}$ of the groundwater level, $83 \%$ of the wells for winter season and $92 \%$ for spring season have positive values for ITA index (Figure 7). Most negative values of the ITA index were observed for the depth of groundwater between 4 and $6 \mathrm{~m}$ for summer and autumn seasons (64.3\% for both). Important negative values for the ITA index were observed for the class between 2 and $4 \mathrm{~m}$ of the groundwater level with $42.35 \%$ of the wells in the spring season and yearly, and $46.2 \%$ of the wells in the summer and autumn season. For the wells with groundwater level over $10 \mathrm{~m}$ depths, the negative values for the ITA index were not calculated.

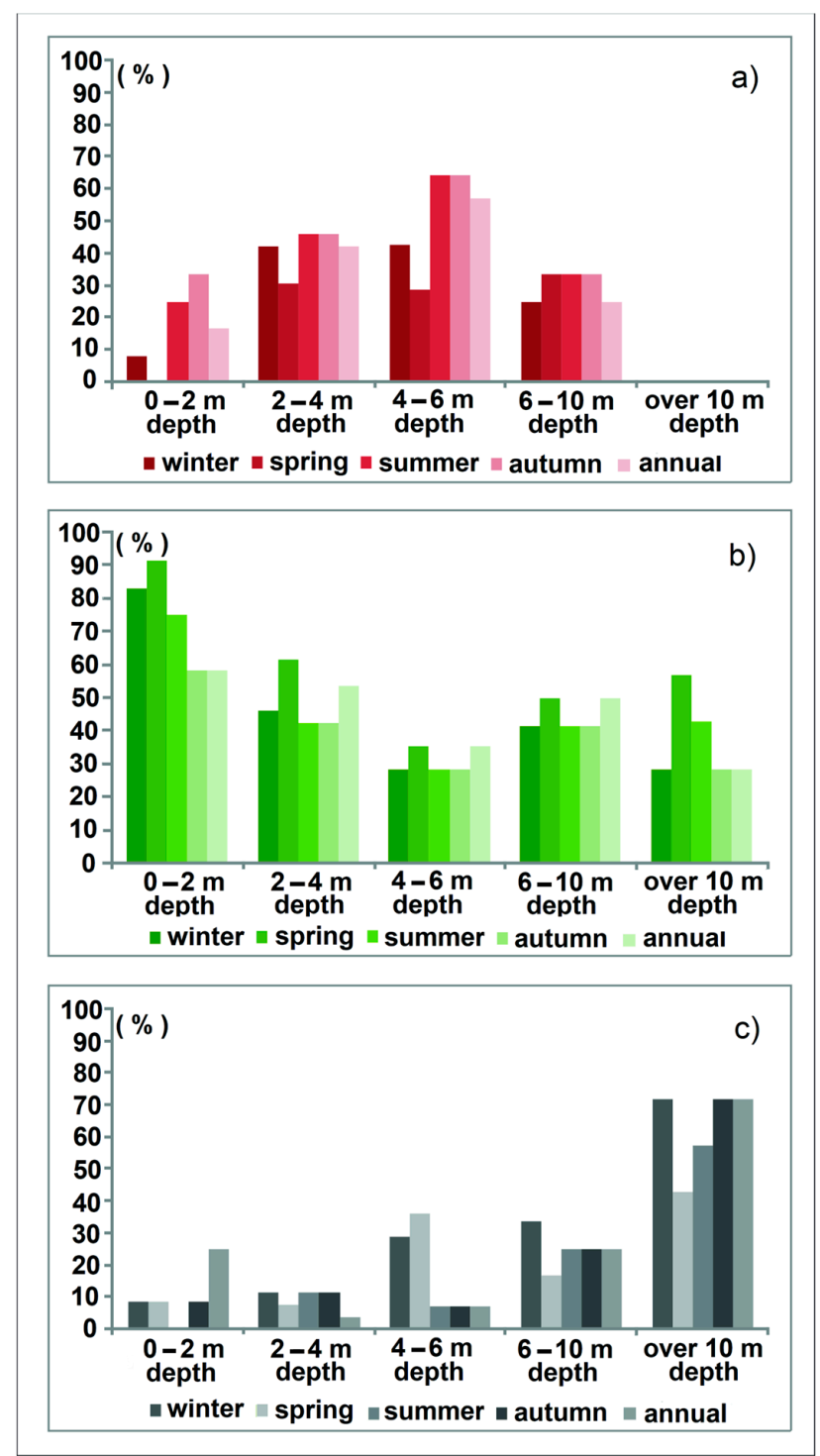

Figure 7. Frequency of positive (a), negative (b), and without statistical significance (c) of ITA index for different classes of groundwater level. 
As we expect, most of the drilling where no significant values of ITA index have been observed, have the groundwater level at depths of over $10 \mathrm{~m}$. At this level, $71.4 \%$ from seven wells included in this class have no significant values for ITA index in winter and autumn season and at the annual level, and 57.1 in summer season. This is determined by the high depth of the groundwater level and the reduction of the influence of surface water (from rivers, wetlands, and lakes).

For different classes of groundwater the values of ITA index records important variations. If for the winter and spring seasons the ITA index values remain positive for all depth classes, with a maximum for the 0 to $2 \mathrm{~m}$ class (1.42 and 2.76 respectively), for the summer and autumn there are negative values of the ITA index for the depth classes ranging from 2 to $4 \mathrm{~m}$ and 4 to $6 \mathrm{~m}$, respectively (Figure 8). Statistical significant are those corresponding to the depth class of 4 to $6 \mathrm{~m}$ with ITA index for the summer season of -1.6 . For annual values, the ITA index has significant positive values for depth classes ranging from 0 to $2 \mathrm{~m}$ (1.13) and over $10 \mathrm{~m}$ depth of groundwater level (0.48).

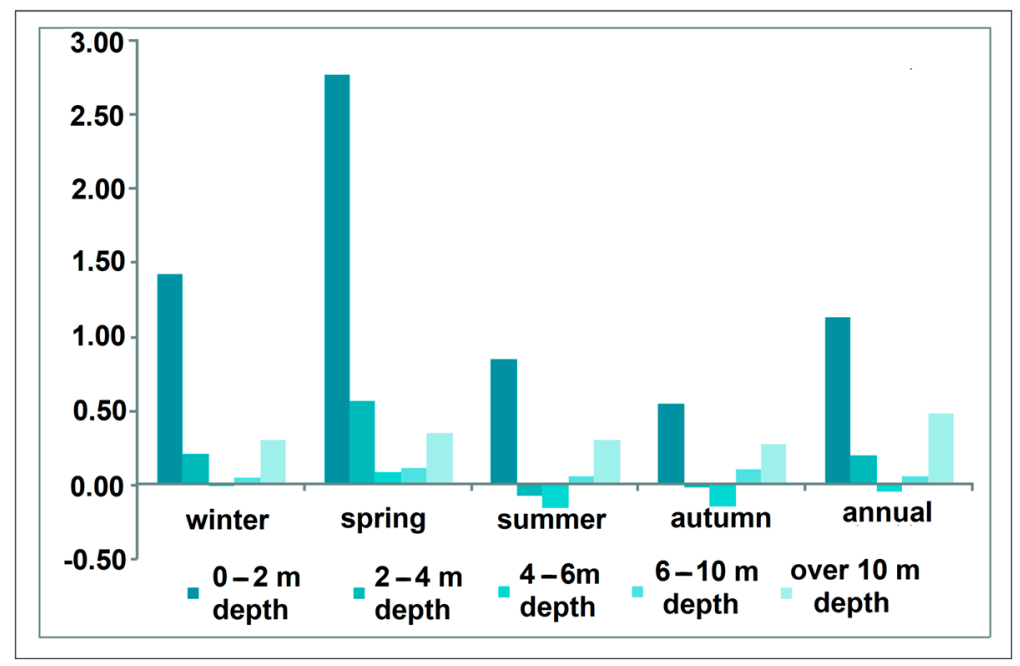

Figure 8. Changes in seasons and annual groundwater level according to the ITA index for different groundwater level depths classes.

These values of the ITA index are consistent with the slope trends identified for groundwater level for different classes. The same concordance is also observed in the spatial distribution of the ITA index where the lower values of the magnitude of the trend are recorded in the south-eastern, central, and south-western parts, and higher in the north and north-west (Figure 9).

These changes in the groundwater level can have a negative impact on the environment. In winter and spring seasons, the decrease in groundwater level, identified for depths of 0 and $2 \mathrm{~m}$ and depths of 2 and $4 \mathrm{~m}$, can have a significant impact on surface water and underground water changes. Decreasing levels for groundwater may lead to lower groundwater quality through faster infiltration of surface water directly or through the hydrographic network [35,36].

Unlike classical methods that use the Mann-Kendall test, Sen's slope, and linear regression [37] to identify trends and their directions (increase, decrease, or constant), the ITA method can be applied to various hydroclimatic parameters. The comparative analysis of data series can be carried out without statistical assumptions [19] and the resulting graphs facilitate the statistical interpretation [38]. The method has been intensively used in the past decade to identify trends on extreme seasonal and annual value sets for climatic and hydrological parameters [39,40]. The ease of tracking trends by comparative analysis of data strings has led to the application of this method to identify solar radiation trends [41] and can be included in the analysis of trends of groundwater levels connected with different extreme hydroclimatic phenomena [42] or climatic changes [43]. 


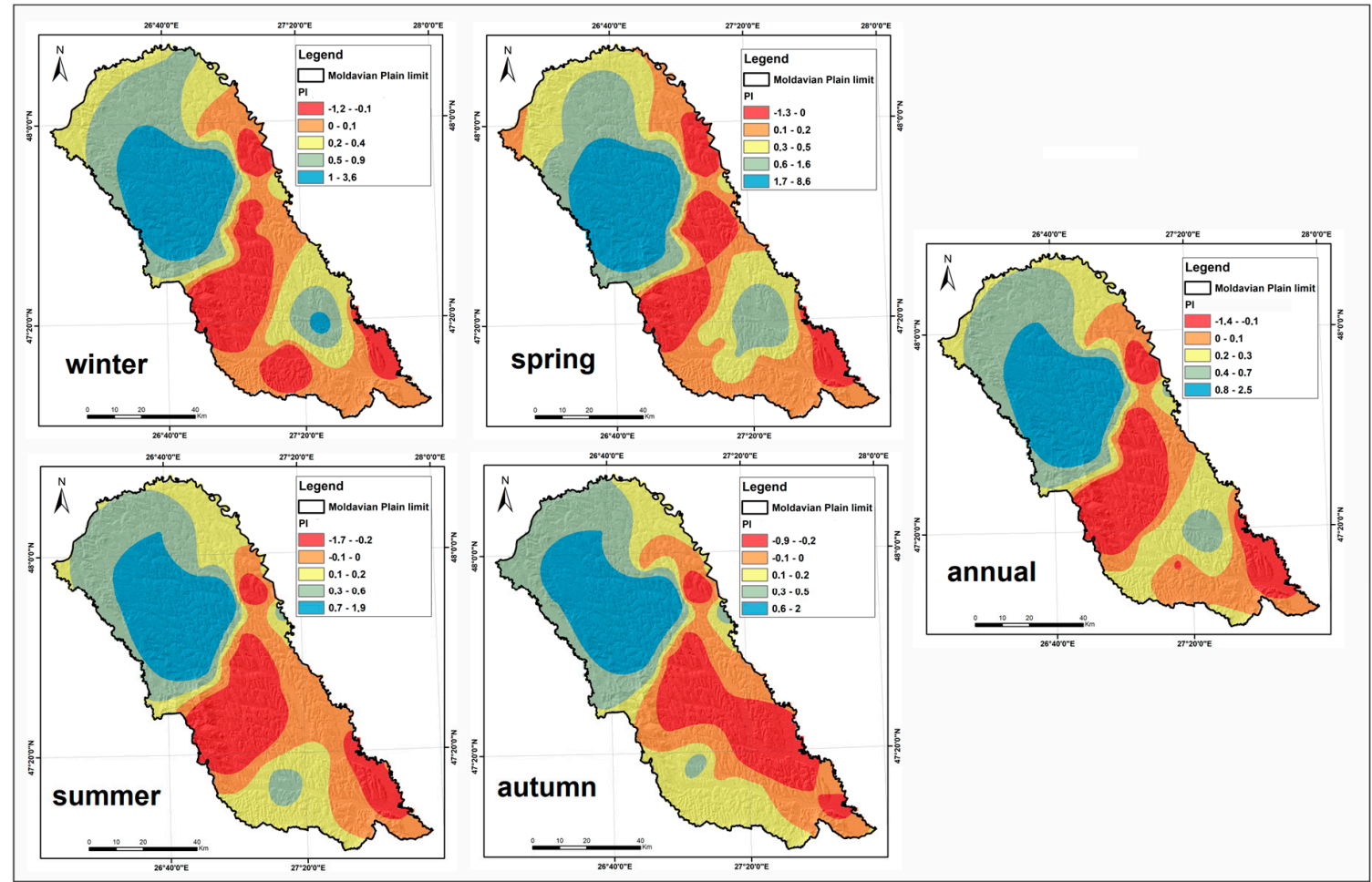

Figure 9. ITA index distribution for annual and seasons periods.

\section{Conclusions}

The main conclusions that can be drawn from the analysis performed for the assessment of groundwater level for wells trends in the north-eastern part of Romania can be summarized as follows:

1. The ITA reveals a general positive trend for groundwater levels over $50 \%$ of wells for annual, winter, and spring seasons. The negative trend for groundwater level was observed for more than $43 \%$ for the autumn season followed by summer season with less than $40 \%$.

2. For different classes of groundwater level, in the winter and spring seasons, for the depth class of 0-2 m, positive trends were observed (with $83 \%$, respectively $92 \%$ of the wells). For groundwater depths between 4 and $6 \mathrm{~m}$, in the summer and autumn season, the most negative trends were observed (with over $64 \%$ of wells).

3. The ITA index indicates a significant positive increase of the groundwater level for the spring and winter season for the groundwater level depth between 0 and $2 \mathrm{~m}$ and 2 and $4 \mathrm{~m}$. Significant negative values of the ITA index were observed for summer and autumn season for the groundwater class of $4-6 \mathrm{~m}$.

Natural processes such as the earlier snowmelt, the shorter snow season, and the longer rainfall season are just a few elements that can substantially modify the hydro-climatic trends with effects on variation of the ground water levels. The results obtained by applying the ITA and associated index can be integrated into current and future local and regional management of underground water resources.

Supplementary Materials: The following are available online at http://www.mdpi.com/2073-4441/12/8/2129/s1.

Author Contributions: Conceptualization, I.M.; methodology, I.M. and D.B.; software, D.B. and O.-E.C.; validation, I.M.; formal analysis, O.-E.C.; investigation, D.B.; resources, I.M.; data curation, I.M.; writing-original draft preparation, D.B.; writing-review and editing, O.-E.C. and D.B.; visualization, I.M.; supervision, I.M.; project administration, I.M.; funding acquisition, I.M., O.-E.C. and D.B. All authors have read and agreed to the published version of the manuscript.

Funding: This research was funded by the grant of Minister of Research and Innovation CNCS-UEFISCDI, project number PN-III-P1-1.1-TE-2019-0286. 
Conflicts of Interest: The authors declare no conflict of interest.

\section{References}

1. Koster, R.D.; Betts, A.K.; Dirmeyer, P.A.; Bierkens, M.; Bennett, K.E.; Déry, S.J.; Evans, J.P.; Fu, R.; Hernandez, F.; Leung, L.R.; et al. Hydroclimatic Variability and Predictability: A Survey of Recent Research. Hydrol. Earth Syst. Sci. 2017, 21, 3777-3798. [CrossRef] [PubMed]

2. Foster, S.; van der Gun, J. Groundwater Governance: Key challenges in applying the Global Framework for Action. Hydrogeol. J. 2016, 24, 749-752. [CrossRef]

3. Tabari, H.; Hosseinzadeh Tallae, P. Temporal variability of precipitation over Iran: 1966-2005. J. Hydrol. 2011, 396, 313-320. [CrossRef]

4. Garamhegyi, Y.; Kovács, J.; Pongrácz, R.; Tanos, P.; Hatvani, I.G. Investigation of the climate-driven periodicity of shallow groundwater level fluctuations in a Central-Eastern European agricultural region. Hydrogeol. J. 2018, 26, 677-688. [CrossRef]

5. Feng, X.; Zhang, G.; Yin, X. Hydrological responses to climate change in Nenjiang River basin, northeastern China. Water Resour. Manag. 2011, 25, 677-689. [CrossRef]

6. Taye, M.T.; Willems, P.; Block, P. Implications of climate change on hydrological extremes in the Blue Nile basin: A review. J. Hydrol. Reg. Study 2015, 4, 280-293. [CrossRef]

7. Mittal, N.; Bhave, A.G.; Mishra, A.; Singh, R. Impact of human intrevention and climate change on natural flow regime. Water Resour. Manag. 2016, 30, 685-699. [CrossRef]

8. Yang, J.; Chang, J.; Yao, J.; Wang, Y.; Huang, Q.; Xu, G. Impact of natural climate variability on runoff based on Monte Carlo method. J. Water Clim. Chang. 2017, 10, 344-359. [CrossRef]

9. Zelenáková, M.; Vido, J.; Portel, M.M.; Purcz, P.; Blištán, P.; Hlavatá, H.; Hluštík, P. Precipitation Trends over Slovakia in the Period 1981-2013. Water 2017, 9, 922. [CrossRef]

10. Taylor, R.G.; Scanlon, B.; Döll, P.; Rodell, M.; van Beek, R.; Wada, Y.; Longuevergne, L.; Leblanc, M.; Famiglietti, J.S.; Edmunds, M.; et al. Ground water and climate change. Nat. Clim. Chang. 2012, 3, 322-329. [CrossRef]

11. Pathak, A.A.; Dodamani, B.M. Trend Analysis of Groundwater Levels and Assessment of Regional Groundwater Drought: Ghataprabha River Basin, India. Nat. Resour. Res. 2019, 28, 631-643. [CrossRef]

12. Sakizadeh, M.; Mohamed, M.A.M.; Klammler, H. Trend Analysis and Spatial Prediction of Groundwater Levels Using Time Series Forecasting and a Novel Spatio-Temporal Method. Water Resour. Manag. 2019, 33, 1425-1437. [CrossRef]

13. Sen, Z. Innovative trend significance test and applications. Theor. Appl. Climatol. 2017, 127, 939-947. [CrossRef]

14. Tabari, H.; Taye, M.T.; Onyutha, C.; Willems, P. Decadal analysis of river flow extremes using quantile-based approaches. Water Resour. Manag. 2017, 31, 3371-3387. [CrossRef]

15. Caloiero, T.; Coscarelli, R.; Ferrari, E. Application of the Innovative Trend Analysis Method for the Trend Analysis of Rainfall Anomalies in Southern Italy. Water Resour. Manag. 2018, 32, 4971-4983. [CrossRef]

16. Wu, H.; Li, X.; Qian, H. Innovative trend analysis of annual and seasonal rainfall and extreme values in Shaanxi, China, since the 1950s. Inter. J. Climatol. 2017, 37, 2582-2592. [CrossRef]

17. Sonali, P.; Nagesh Kumar, D. Review of trend detection methods and their application to detect temperature changes in India. J. Hydrol. 2013, 476, 21-217. [CrossRef]

18. Kisi, O.; Ay, M. Comparition of Mann-Kendall and innovative trend method for water quality parameters of Kizilirmak River, Turkey. J. Hydrol. 2014, 513, 362-375. [CrossRef]

19. Dabanli, I.; Șen, Z.; Yelegen, M.O.; Șișman, E.; Selek, B.; Guclu, Y.S. Trend assesment by the innovative Șen Method. Water Resour. Manag. 2016, 30, 5193-5203. [CrossRef]

20. Prăvălie, R.; Piticar, A.; Roșca, B.; Sfîcă, L.; Bandoc, G.; Tiscovschi, A.; Patriche, C.V. Spatio-temporal changes of the climatic water balance in Romania as a response to precipitation and reference evapotranspiration trends during 1961-2013. Catena 2018, 172, 295-312. [CrossRef]

21. Croitoru, A.E.; Piticar, A.; Sfica, L.; Harpa, G.V.; Rosca, C.F.; Tudose, T.; Horvath, C.; Minea, I.; Ciupertea, F.A.; Scripca, A.S. Extreme Temperature and Precipitation Events in Romania; Romanian Academy Press: Bucharest, Romania, 2018. 
22. Croitoru, A.E.; Minea, I. The impact of climate changes on rivers discharge in Eastern Romania. Theor. Appl. Climatol. 2015, 3-4, 1434-4483. [CrossRef]

23. Minea, I.; Chelariu, O.E. Anomalies and trends of high river flow under temperate climatic conditions in north-eastern part of Romania. J. Water Clim. Chang. 2020. [CrossRef]

24. Minea, I.; Croitoru, A.E. Groundwater response to changes in precipitations in north-eastern Romania. Environ. Eng. Manag. J. 2017, 16, 643-651. [CrossRef]

25. Ionesi, L.; Ionesi, B.; Rosca, V.; Lungu, A.; Ionesi, V. Middle and Upper Sarmatian on Moldavian Platform; Romanian Academy Press: Bucharest, Romania, 2005. (In Romanian)

26. Sandu, I.; Pescaru, V.I.; Poiana, I. Climate of Romania; Romanian Academy Press: Bucharest, Romania, 2008. (In Romanian)

27. Croitoru, A.E.; Piticar, A.; Burada, D.C. Changes in precipitation extremes in Romania. Quat. Intern. 2016, 415, 325-335. [CrossRef]

28. Bîrsan, M.V.; Zaharia, L.; Chendes, V.; Branescu, E. Seasonal trends in Romanian streamflow. Hydrol. Process. 2014, 28, 4496-4505. [CrossRef]

29. Minea, I.; Croitoru, A.E. Climate Changes and their impact on the variation of groundwater level in the Moldavian Plateau (Eastern Romania). In Proceedings of the 2015 SGEM International Multidisciplinary Scientific Geoconferences, Albena, Bulgaria, 18-24 June 2015; pp. 137-145. [CrossRef]

30. Sen, Z. Innovative trend analysis methodology. J. Hydrol. Eng. 2012, 17, 1042-1046. [CrossRef]

31. Haktanir, T.; Citakoglu, H. Trend, independence, stationarity, and homogeneity tests on maximum rainfall series of standard durations recorded in Turkey. J. Hydrol. Eng. 2014, 19, 9. [CrossRef]

32. Wu, H.; Li, X.; Qian, H. Detection of anomalies and changes of rainfall in the Yellow river basin, China, through two graphical methods. Water 2018, 10, 15. [CrossRef]

33. Minea, I.; Butelcă, D.; Niacşu, L. Groundwater level variation patterns in drought conditions. Case study Bârlad upper basin. Geogr. Napoc. 2012, 1, 75-82. (In Romanian)

34. Yong, X.; Xiaomin, G.; Shiyang, Y.; Jingli, S.; Yali, C.; Qiulan, Z.; Yong, N. Geostatistical interpolation model selection based on ArcGIS and spatio-temporal variability analysis of groundwater level in piedmont plains, northwest China. Springer Plus 2016, 5, 425. [CrossRef]

35. Minea, I. Bahlui Drainage Basin-Hydrological Study; Al.I.Cuza Press: Iași, Romania, 2012. (In Romanian)

36. Repel, A.; Jothiprakash, V.; Zelenáková, M.; Hlavatá, H.; Minea, I. Temporal Analysis of Daily and 10 Minutes of Rainfall of Poprad Station in Eastern Slovakia. Hydrology 2020, 7, 32. [CrossRef]

37. Bürger, G. On trend detection. Hydro. Proc. 2017, 31, 4039-4042. [CrossRef]

38. Guslu, Y.S. Improved visualization for trend analysis by comparing with classical Mann-Kendall test and ITA. J. Hydroloy 2020, 584, 584. [CrossRef]

39. Alifujiang, Y.; Abuduwaili, J.; Maihemuti, B.; Emin, B.; Groll, M. Innovative Trend Analysis of Precipitation in the Lake Issyk-Kul Basin, Kyrgyzstan. Atmosphere 2020, 11, 332. [CrossRef]

40. Caloiero, T. Evaluation of rainfall trends in the South Island of New Zealand through the innovative trend analysis (ITA). Theor. Appl. Climatol. 2019, 139, 493-504. [CrossRef]

41. Zhou, Z.; Wang, L.; Lin, A.; Zhang, M.; Niu, Z. Innovative trend analysis of solar radiation in China during 1962-2015. Renew. Energy 2018, 119, 675-689. [CrossRef]

42. Halder, S.; Roy, M.B.; Roy, P.K. Analysis of groundwater level trend and groundwater drought using Standard Groundwater Level Index: A case study of an eastern river basin of West Bengal, India. SN Appl. Sci. 2020, 2, 507. [CrossRef]

43. Li, H.; Lu, Y.; Zheng, C.; Zhang, X.; Zhou, B.; Wu, J. Seasonal and Inter-Annual Variability of Groundwater and Their Responses to Climate Change and Human Activities in Arid and Desert Areas: A Case Study in Yaoba Oasis, Northwest China. Water 2020, 12, 303. [CrossRef]

(C) 2020 by the authors. Licensee MDPI, Basel, Switzerland. This article is an open access article distributed under the terms and conditions of the Creative Commons Attribution (CC BY) license (http://creativecommons.org/licenses/by/4.0/). 